\title{
Documentação
}

\section{O Uso de Fotografias de Africanos no Estudo Etnográfico de Manuel Querino ${ }^{1}$}

\author{
Christianne Silva Vasconcellos ${ }^{2}$
}

\section{RESUMO}

Este artigo analisa o ensaio etnográfico empreendido por Manuel Raimundo Querino: A raça africana e seus costumes na Babia, procurando, sobretudo, entender a maneira como o autor utilizou a terminologia do evolucionismo social para destacar os aportes dos africanos na cultura baiana. O ensaio contém fotografias de pessoas africanas, autoridades do candomblé, festividades e objetos da cultura material dessa religião, as quais serviram de suporte visual na etnografia feita pelo autor. $\mathrm{O}$ uso dado por Querino às imagens e a análise da cultura africana no marco do evolucionismo social resulta particular quando comparado com outras os estudos acerca dos africanos na Bahia no inicio do século XX.

Palavras-chave: Etnografia, Fotografias, Africanos, Evolucionismo social, Bahia Oitocentista, Manoel Querino.

\section{ABSTRACT}

This article analyzes the ethnographic essay undertaken by Manuel Raimundo Querino: $A$ raça africana e seus costumes na Babia. The objective is to understand the way in which the author used the socio-evolutionist terminology to enhance the contributions of the African people to Bahia's cultures. In the essay Querino exhibited various photographs of African people, as well as of Candomble authorities, rituals, and material objects. Those pictures served the author as visual supports to his ethnography. Here I analyze the use given by Querino to the images, which results particular if compared with other researches did about African people in Bahia during the same period.

Keywords: Ethnography, Photography, Africans, socio-evolutionism, nineteenth-century Bahia, Manuel Querino.

Em 1916, Manuel Raimundo Querino apresentou o ensaio "A raça africana e seus costumes na Babia”, no $5^{\circ}$ Congresso Brasileiro de Geografia, ocorrido na cidade de Salvador entre 07 e 15 de setembro. O ensaio constitui um estudo etnográfico dos povos africanos na Bahia, por meio da análise da religião, estratégias laborais e sociais praticadas pela população africana em Salvador. Foram utilizadas, como fonte de informação, a fotografia a e memória oral dos mesmos africanos e seus descendentes, residentes em Salvador, na primeira década do século XX. Os argumentos desenvolvidos são, em parte, sustentados a partir dos depoimentos de "velhos respeitáveis", com os quais Querino sugere ter mantido relações de solidariedade e amizade. ${ }^{3}$

\footnotetext{
${ }^{1}$ Agradeço à Paola Vargas, Jacimara Santana e aos membros da Linha de pesquisa "Escravidão e Invenção da Liberdade" do Programa de Pós Graduação em História (UFBA) pelos seus comentários a uma versão preliminar desse texto. Comunicação apresentada no Seminário Manuel Querino, Vida e Obra, IGHBa, Salvador, 27/08/2008.

2 Mestre em História Social pela Universidade Federal da Bahia (2006). Título da dissertação "O circuito social das fotografias da Gente Negra. Salvador 1860-1916".

${ }^{3} \mathrm{O}$ autor, em nenhum momento, afirma que pertencia à religião à qual se refere. Destacou a reserva mantida pelos africanos com relação aos rituais religiosos e a relação de confiança que estabeleceu com seus informantes: "notícia que colhemos de velhos respeitáveis e que nol'a deram sem reservas nem subterfúgios,
} 
Neste artigo, destaco que o ensaio é pioneiro na utilização de fotografias para produção historiográfica sobre a temática de africanos na Bahia. Em outro trabalho, utilizei o ensaio como fonte para identificar usos e sentidos da fotografia na Bahia oitocentista até o ano de 1916. ${ }^{4}$ Alguns retratos não foram produzidos com a vocação específica de servir ao ensaio de Querino, e, sim, com fins comerciais, ocorrendo uma mudança de sentido no ensaio de Querino. De modo diferente, aquelas da cultura material do candomblé, fogem do padrão comercial e, portanto, podem ter sido feitas especificamente para esta análise etnográfica, sem com isso seguir o padrão da fotografia etnográfica.

Nesta perspectiva, o artigo analisará a terminologia que Querino utilizou, para identificar as fotografias, e aquela desenvolvida, no mesmo período, pelo evolucionismo social. Porém, à diferença de autores contemporâneos como Nina Rodrigues ou Silvio Romero, que usaram o evolucionismo para localizar os africanos e seus descendentes num estágio inferior de desenvolvimento, Querino identificou as contribuições dessas populações na construção da sociedade brasileira. Por outra parte buscará identificar os aspectos fundamentais da abordagem etnográfica desenvolvida pelo autor e de que maneira tal procedimento possibilitou uma visão positiva dos africanos na Bahia.

"A Raça africana e seus costumes na Bahia" apresenta vinte e três fotografias, sendo quinze retratos de homens e mulheres negras, cinco fotografias de objetos votivos, três fotografias de esculturas e duas gravuras. Destaca-se o valor documental da coleção, pois alguns retratos somente são conhecidos por intermédio da publicação do ensaio. Em particular, as fotografias da escultura dos orixás, a cascata da sereia - Pegi do Candomblé do Gantois, o altar mor do Pegi, o santuário de Humoulu e os instrumentos musicais de origem africana constituem um registro inédito da cultura material do candomblé. São reproduzidas abaixo as imagens do ensaio na mesma ordem que aparecem no texto. Todas elas receberam o termo "estampa", foram numeradas com algarismos romanos e identificadas seguindo a terminologia etnográfica da época.

porque em nós essas pessoas não viam mais que um amigo de sua raça, ou quem com sincera sympatia, sempre respeitou e soube fazer justiça à gente que o cativeiro aviltou, insultou e perseguiu, mas que não logrou jamais alterar-lhe as qualidades innatas, affectivas". Querino, 1917 p.7. Ao longo do ensaio, Querino cita o terreiro do Gantois e o candomblezeiro Manuel de Xangô. Para uma etnografia dos candomblés da Bahia ver: Pares, Nicolau. A Formação do Candomblé - História e Ritual da Nação Jeje na Babia, Campinas, Ed. Unicamp, 2007. Reis, João José. Domingos Sodré: um sacerdote africano. Escravidão, liberdade e Candomblé na Babia do século XIX. São Paulo, Cia das Letras, 2008; Castilho, Lisa E. Entre a oralidade e a escrita: etnografia nos candomblés da Babia, Salvador, Edufba, 2009. Lisa Earl Castillo e Luis Nicolau Parés "Marcelina da Silva e seu mundo: novos dados para uma historiografia do candomblé ketu "Afro-Asia, n.36, 2007.

${ }^{4}$ Este artigo é parte do capítulo 3 da minha dissertação de mestrado: VASCONCELLOS, Christianne, "O circuito social das fotografias da Gente Negra. Salvador 1860-1916”. Salvador, UFBA, 2006. 


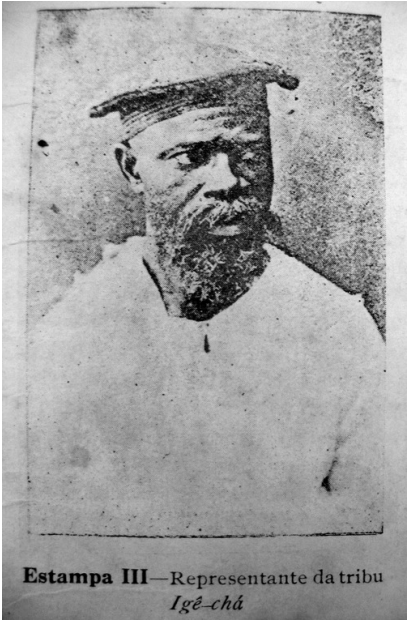

Estampa III Representante da Tribu Igê Chá

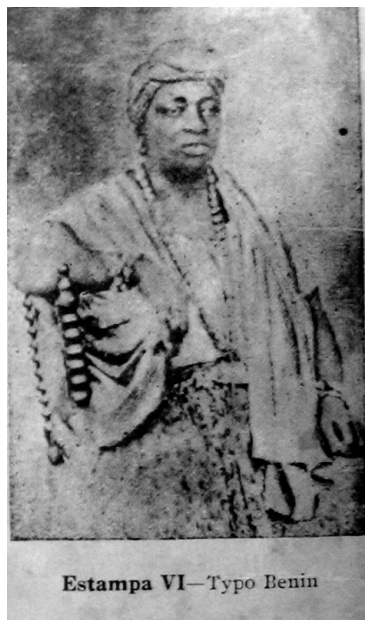

Estampa VI Typo Benin

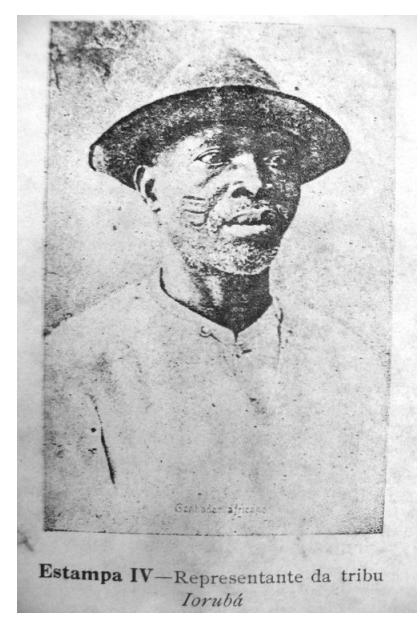

Estampa IV Representante da

Tribu Iorubá

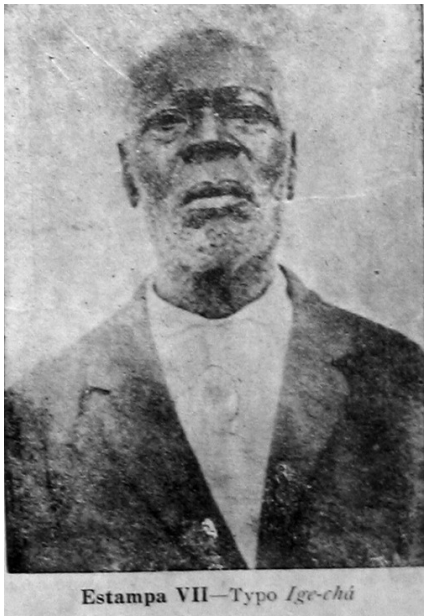

Estampa VII Typo Igê Chá

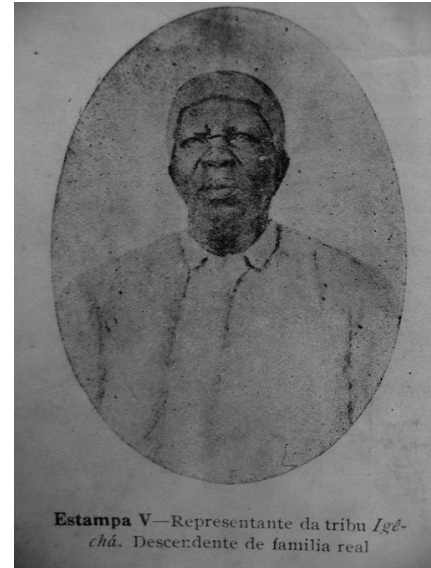

Estampa V Representante da Tribu Igê Chá. Descendente de Família Real

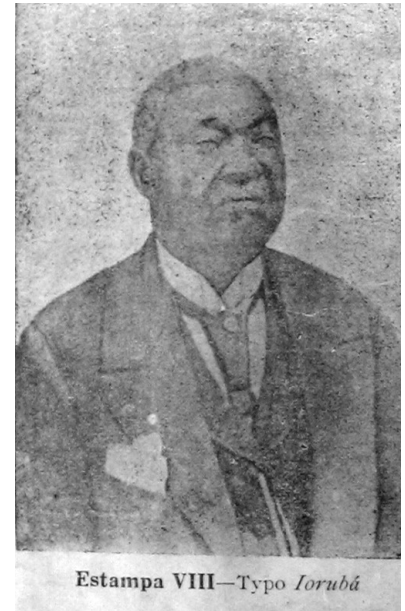

Estampa VIII Typo Iorubá

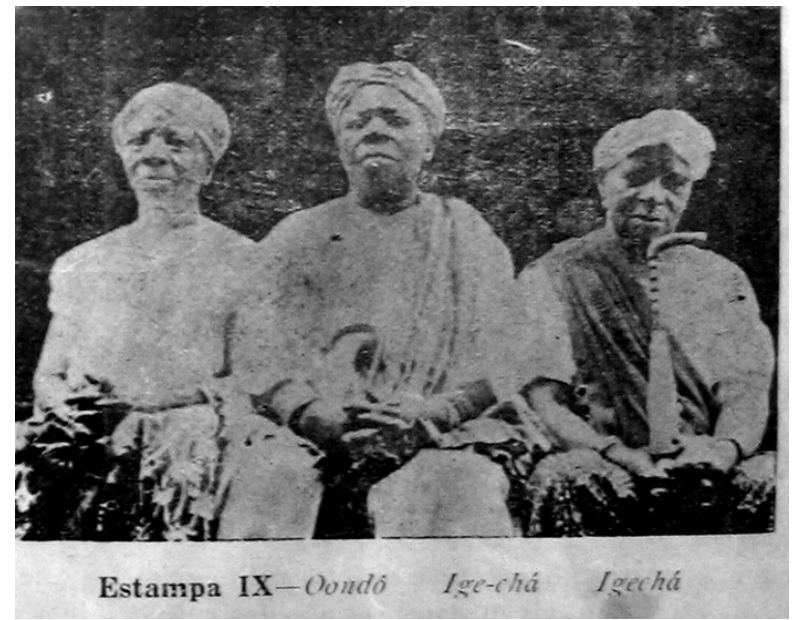

Estampa IX Oondó, Igê Chá, Igê Chá 


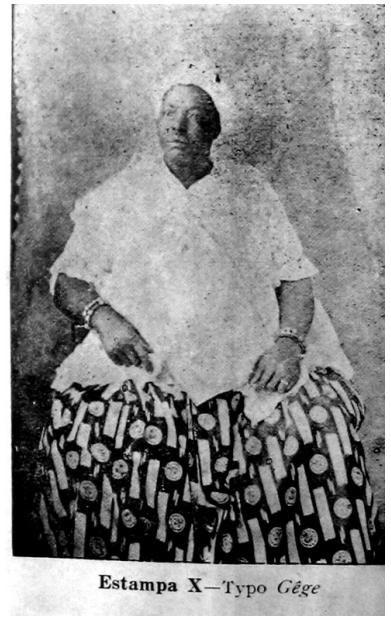

Estampa X. Typo Gegê

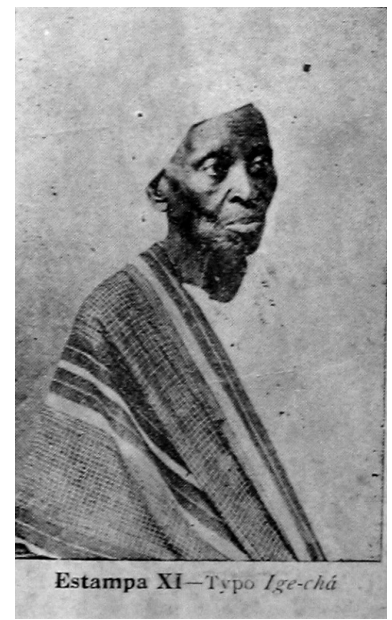

Estampa XI Typo Igê Chá

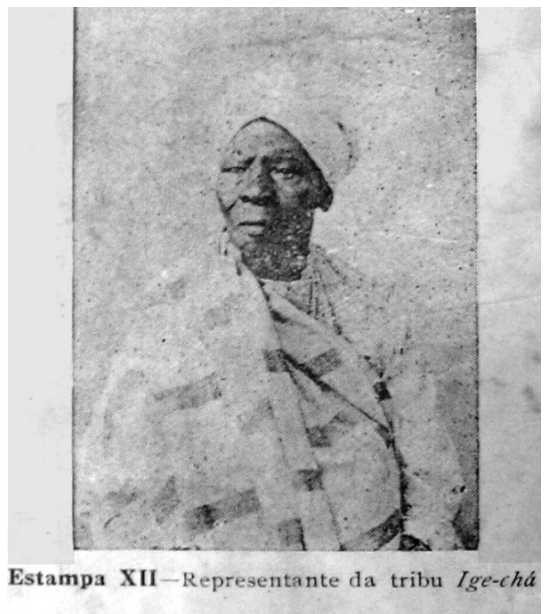

Estampa XII Representante da Tribu Igê Chá

Nas legendas que acompanham cada fotografia, Querino especificou a presença de pessoas das etnias iorubá, ondô, egbá e ijexá, todas falantes da língua iorubá, que, na Bahia, foram denominadas nagô. A identificação do autor é corroborada pelos dados do tráfico transatlântico, que informam serem esses povos provenientes da região interior do Golfo do Benin, principalmente da atual Nigéria e leste da República do Benin. Os conflitos ocorridos nessa região, no início do século XIX, produziram migrações e guerras locais cujas vítimas foram escravizadas e vendidas principalmente para o Brasil e Cuba. ${ }^{5}$

No final do século XIX, o termo "iorubá”, originalmente usado pelos haussás para designar apenas os oiós, seus vizinhos, foi estendido no sul da África Ocidental a todos os falantes de uma mesma língua, que também foi designada iorubá. Segundo Matory, na virada do século XIX, "agentes culturais negros" elaboraram uma cultura unitária, com base na padronização da língua iorubá e na afirmação do valor da cultura iorubá. Estes agentes estavam conformados por uma elite africana educada na Inglaterra, incluídos pastores recém-convertidos e afro-americanos, inicialmente instalados na cidade de Freetown em Serra Leoa e, posteriormente, em Lagos. A este grupo se uniram afrobrasileiros retornados para essa cidade. A idéia de superioridade do povo iorubá era difundida por estes agentes que se dedicaram a argumentar, na África Ocidental, Inglaterra e Brasil, a favor da sofisticação e dos aspectos civilizatórios de sua cultura como forma de

5 VERGER, Pierre. Fluxo e refluxo do tráfico de escravos entre o golfo do Benin e a Babia de Todos os Santos dos séculos XVII ao XIX. Salvador, Corrupio, 2002 
resistir às pressões do colonialismo. ${ }^{6}$ Entretanto, no ensaio de Querino, as populações aparecem em sua especificidade étnica. Por exemplo, quando o autor especifica "tipo iorubá", provavelmente se referiu apenas às pessoas de Oió. Isto sugere que a unidade iorubá, em construção na África, ainda não tinha um paralelo entre a população da África Ocidental na Bahia.

Por outra parte, o termo nagô não foi mencionado entre os "typos". Isto pode referir-se ao fato de Querino querer evitar qualquer generalização, pois nagô era o termo usado para denominar africanos da África Ocidental. Esse dado é relevante, pois demonstra a riqueza etnográfica apresentada pelo autor, que individualizou os aportes culturais de povos que, até mesmo na África, estavam se misturando e redefinindo.

A etnia mais recorrente nas legendas das fotografias usadas por Querino é a dos ijexás. Isto coincide com o fato de essa etnia estar entre as principais vítimas da última década do tráfico baiano. ${ }^{7}$ Portanto, essa população sobreviveu ao fim da escravidão em maior número que outros grupos. Outra hipótese relevante é a do candomblé estudado por Querino ser formado por uma maioria ijexá. Um desses ijexás (Est.V) foi identificado pelo autor "como descendente de família real", dado corroborado pelo cônsul inglês James Wetherell que, em 1843, escreveu sobre a existência de "príncipes pretos" em Salvador que eram cumprimentados e reverenciados por seus conterrâneos na sua língua nativa. ${ }^{8}$

Os termos typo e representante, com os quais Querino identifica as fotografias, foram usados também nos estudos antropológicos da época, como os de Louis Agassiz e Nina Rodrigues. Esses estudos classificavam as populações no marco do evolucionismo social, cujo projeto taxonômico aplicado à natureza, rapidamente foi utilizado para explicar o estágio evolutivo das distintas sociedades humanas. Querino, todavia, se diferenciou dos outros autores evolucionistas, quando demonstrou a diversidade étnica dos africanos como um valor social do Brasil.

Para entender a particularidade dos argumentos de Querino, torna-se necessário entender, primeiro, o processo de constituição do evolucionismo social na Europa, e, em seguida, como esta tendência foi interpretada pelos investigadores no Brasil. Ao analisar o projeto, Johannes Fabian afirmou que os evolucionistas sociais “espacializaram” o tempo:

\footnotetext{
${ }^{6}$ MATORY, J. Lorand. The english professors of Brazil: On the diasporic roots of tuhe Yorubá Nation. Comparative Studies in Society and History, n. 1 vol. 41 Cambridge.

7 PEEL. J. D. Y. Religious Encounter and the Making of the Yoruba. Indiana University Press, 2003, p.28-30. VERGER, op.cit. 233-256.

8 WETHERELL, James. Brasil, Apontamentos sobre a Babia. Salvador, Edição Banco da Bahia S/A, p. 18.
} 
o paradigma evolutivo se assentou numa concepção do tempo que não era somente secular e naturalizado, mas também profundamente espacializado. $\mathrm{O}$ eixo do tempo foi projetado sobre o eixo do espaço, e a história se tornou global. Com o Darwinismo social, o projeto taxonômico, primeiro aplicado à natureza, se aplicava agora à história cultural. O tempo tornou-se uma geografia do poder social, um mapa onde se exibia uma alegoria global das "naturais" diferenças sociais. ${ }^{9}$

A análise de Fabian mostra que a nova concepção de tempo, nascida da teoria evolucionista de Darwin, foi usada para entender as diferenças entre as sociedades humanas, classificando-as dentro de uma escala hierárquica. Nesse sentido, supunha-se que cada formação social, apesar de existir simultaneamente, exibia um estágio diferente na cadeia evolutiva humana destinada a alcançar a civilização. De fato, construiu-se um modelo de desenvolvimento unilinear da história humana em que todos tinham que alcançar o estágio mais elevado, aquele dos europeus, o único considerado “civilização”. Só as sociedades urbanizadas e com escrita mereciam esse qualificativo por seu desenvolvimento tecnológico, capacidade de organizar estados burocráticos, superioridade linguística e monoteísmo cristão.

Nesse tempo espacializado pelos europeus, os africanos foram classificados nos estágios primitivos de desenvolvimento. Sua organização política foi denominada tribal, com líderes carismáticos ou teocracias, sua religião denominada de crenças fetichistas, seitas e ídolos e sua língua considerada dialetos alheios à escrita. O espaço global contemporâneo a Querino converteu-se numa vitrine da evolução social e todos os grupos foram classificados e localizados no estágio evolutivo pelo qual teriam que passar todas as sociedades humanas.

Foram essas as bases teóricas utilizadas por Louis Agassiz e, logo depois, pelos professores da Faculdade de Medicina da Bahia como Nina Rodrigues, contemporâneo de Manuel Querino. Agassiz, professor da Universidade de Harvard, esteve no Brasil entre 1865 e 1866, defendendo e difundindo as idéias do racialismo científico entre os brasileiros. Agassiz esteve nas regiões amazônica e nordestina, onde realizou estudos sobre a mestiçagem brasileira e africana no Brasil. Adepto da teoria poligenista, afirmava tanto a diversidade de raças na espécie humana, como os diferentes estágios de desenvolvimento nas quais as raças localizavam-se.

Agassiz promoveu e dirigiu séries fotográficas de africanos escravizados, mestiços e indígenas no Brasil, seguindo as convenções desenvolvidas pelo darwinismo social, as quais

${ }^{9}$ FABIAN, Johannes. Time and the other: how anthropology makes its objects, New York, Columbia University Press, 1983, p.14-15. 
foram utilizadas em suas investigações sobre tipologias raciais. As fotografias foram realizadas por Walter Hunnewell, membro da comissão de Agassiz, e Augusto Stahl e Germano Wahnschaffe, fotógrafos alemães instalados com ateliê no Rio de Janeiro desde 1863. ${ }^{10}$ A composição deste tipo de fotografia consistia num cenário sem detalhes de fundo, num espaço estreito, onde o sujeito era colocado nu, sozinho, posando em diversos ângulos: perfil, frente e costas. Era incluída uma régua no quadro para medir as proporções corporais das pessoas denominadas "raças". O foco e iluminação favoreciam o detalhamento dos traços físicos do retratado. Os olhos eram captados quando baixos ou direcionados para fora do quadro e, num mesmo arranjo, podia-se ver o sujeito de frente, de perfil e de costas. Por último, as imagens eram dispostas de modo a sugerir um "catálogo de espécies". ${ }^{11}$ Esse tipo de fotografia localizava a diferença no corpo, e utilizava a imagem como registro para classificação dos tipos humanos não europeus.

As fotografias utilizadas por Querino não foram produzidas com finalidade de registro dos tipos humanos e, por isso, apresentam uma composição distinta. Produzidas alguns anos antes da publicação do ensaio, a maioria das fotografias data do final do século XIX e dos primeiros anos do XX. Parte da coleção (estampa III, IV, XVIII) era constituída de fotografias públicas, produzidas em séries denominadas "tipos urbanos" da Bahia, no suporte de bilhete postal ou carte-cabinet, comercializadas nos ateliês dos fotógrafos, em livrarias ou em lojas de artigos para presentes e produtos de uso doméstico. Anunciadas nos jornais como fotografias de "tipos", traziam legendas que destacavam ocupação, cor ou origem do retratado, como "carregador", "ganhadeira”, crioula ou africano. Tais legendas demonstram que termos usados durante a escravidão, em particular aqueles que implicavam um status social diferenciado entre as pessoas negras, permaneceram em uso, no período posterior à abolição do regime.

As legendas de typo e representante, feitas por Querino, exibem os termos da epistemologia científica, o que o aproximou das idéias do evolucionismo. Não obstante usar conceitos racialistas de sua época, o autor identificou as habilidades laborais, tecnológicas e artísticas particulares a cada etnia africana, como aportes civilizatórios na formação social da Bahia. O autor afirma que, mesmo sendo escravos e carecendo de numerosos atributos materiais para seu desenvolvimento, esses povos contribuíram

\footnotetext{
${ }^{10}$ KOSSOY, Boris. Dicionário histórico-fotográfico brasileiro: fotógrafos e oficios da fotografia no Brasil (1833-1910). São Paulo, Instituto Moreira Sales, 2002.

11 ALINDER, Jasmine. La retórica de la desigualdad: Las fotografias de los escravos del Brasil em el siglo XIX. In História y memória: sociedad, cultura y vida cotidiana en Cuba 1878-1917, La Habana, Centro de Investigación y Desarrollo de la Cultura Cubana Juá Marinello. 2003. A referida coleção se encontra hoje no Museu Peabody da Universidade de Harvard.
} 
fortemente para a civilização brasileira. Com isso, ele combateu diretamente as idéias predominantes em seu tempo, que desvalorizavam o trabalho africano e dos seus descendentes, como inferior àquele do imigrante europeu.

As características físicas e comportamentais das mulheres foram associadas por Querino à adaptação ao trabalho. As jejes foram consideradas "as mais amorosas quanto à função da maternidade" e, por isso, "se distinguiam pela correcção esculptural; não tinham o rosto recortado de linhas e costumavam pintar a pálpebra inferior, com uma tinta azul, por faceirice ou enfeite". O destaque dessas características opõe-se ao discurso dos médicos da Faculdade de Medicina da Bahia, os quais consideravam que as amas de leite africanas, além de transmissoras de doenças, eram isentas de valores morais. Um exemplo desse discurso médico encontra-se em uma tese defendida em 1855. Seu autor argumenta que as amas de leite deveriam apresentar qualidades que passassem não somente por atributos físicos, mas, sobretudo, por atributos morais. Afirmava ainda ser difícil encontrar, numa mesma pessoa, todos os atributos necessários a uma nutriz ideal, principalmente no Brasil,

onde as mulheres dadas a este mister são ordinariamente africanas, estuppidas, imoraes, sem educação, sem belleza, sem religião, baldas de sentimentos affectuosas, mal feitas, irasciveis, mal asseiadas, odientas, deleixadas, de pelle rude, trazendo muitas vezes comsigo dessas moléstias que se podem transmitir por meio do aleitamento. Entre nós creio dever-se sempre preferir a ama livre. ${ }^{12}$

Mesmo utilizando tipologias físicas associadas a atributos morais e laborais, Manuel Querino se opôs às ideologias racialistas, destacando o valor da ativa participação dessa população na sociedade baiana.

Por que a antropologia, desde o século XIX, se valeu do fenótipo para identificar o pertencimento cultural da pessoa? Segundo os Comaroff, no século XIX, ocorreu um corte histórico na epistemologia científica, marcando a diferença entre o cronista do século XVI e o naturalista do XIX. Em meio a essa transformação, a utilização de imagens foi fundamental, pois, se nos séculos anteriores as diferenças dos povos e nações eram narradas através dos fatos e circunstâncias, com o surgimento da fotografia, considerada réplica do real, procurou-se registrar todo o mundo visível para, posteriormente, organizálo, ordená-lo e classificá-lo. ${ }^{13}$

\footnotetext{
12 VIANNA, Joaquim Telesphoro Ferreira L. Breves consideraçôes sobre o aleitamento materno, (Tese apresentada à Faculdade de Medicina da Bahia, 1855), p.24. Arquivo da Faculdade de Medicina da UFBA, Salvador - Bahia. 13 COMOAROFF, Jean e John. Of revelation and revolution: Christianity, Colonialism and Consciousness in South África, Chicago, The University of Chicago Press, 1991, vol. 1. p. 86-125
} 
Além disso, numa apropriação dos paradigmas darwinista de "seleção natural", "evolução" e "hereditariedade", desenvolveu-se uma interpretação biológica do corpo humano extensiva à cultura, em que não somente as diferenças físicas, mas também as culturais seriam vistas como resultado de leis orgânicas e naturais. Com base na "nova biologia", o conceito de evolução se constituiu como o paradigma da época e todos os povos e raças passaram a ser hierarquizados em função de seus caracteres físicos, mentais e morais. ${ }^{14}$ Nesta hierarquia, as imagens dos corpos dos africanos refletiriam o estágio da sua cultura. Em particular, foram classificados no nível mais primitivo da escala evolutiva. Ao tratar a África e seus habitantes como selvagens, a literatura dos viajantes naturalistas se empenhou em apresentar descrições "exatas", tanto do corpo como dos costumes. ${ }^{15} \mathrm{O}$ africano representava a transição entre a animalidade e a humanidade e a explicação desse lugar inferior estava na cor da pele e nas formas do corpo. A entrada da fotografia significou a possibilidade de reproduzir objetivamente esses "corpos", como afirma Edwards,

\begin{abstract}
[a fotografia] torna-se uma metáfora do poder tendo a capacidade de descontextualizar e se apropriar do tempo e do espaço e daqueles que existem dentro dele. [...] A fotografia auxiliou o processo de tratar abstrações como objetos materiais na medida em que as criações da mente tornaram-se realidades concretas, observadas, registradas no olho mecânico da câmara. Através da fotografia, por exemplo, o "tipo", a essência abstrata da variação humana, foi percebido como sendo uma realidade observável. O detalhe inevitável criado pelo fotógrafo transforma-se em um símbolo para o todo e induz o expectador a admitir o específico como generalidade tornando-se um emblema de verdades mais vastas, sob o risco de estereotipar e deturpar. ${ }^{16}$
\end{abstract}

De fato, as fotografias tornaram-se ferramentas indispensáveis para descrever povos e culturas na perspectiva das elaborações racialistas da antropologia. Por Querino ter acrescentado às etnias o aposto "tipo" ou "representante", isto demonstra seu acesso a estes discursos racialistas nos quais as heranças físicas estabeleciam uma relação direta entre o corpo e as manifestações culturais. A metodologia utilizada por essa tendência, como explicam os Comaroff, era associar o fenótipo de uma pessoa com a cultura à qual ela pertencia. Um segundo passo da mesma metodologia consistia em localizar o lugar que esse fenótipo ocupava dentro da hierarquização feita pelo evolucionismo cultural. Uma vez associado o fenótipo ao comportamento, o cientista não necessitava mais se referir ao comportamento, pois, com o fenótipo, localizava o indivíduo dentro da hierarquia

\footnotetext{
${ }^{14}$ EDWARDS, Elizabeth. "Antropologia e Fotografia" Cadernos de Antropologia e Imagem 2. Rio de Janeiro, 1996, p.14.

${ }^{15}$ COMAROFF, op. cit. 108

${ }^{16}$ EDWARDS, op.cit. p.16-17
} 
darwinista. ${ }^{17}$ A invenção da "mulher hottentote", a mais conhecida estereotipia sobre as mulheres africanas, foi criada nas expedições científicas européias do século XIX na África do sul. Sob o pretexto de buscar "amostras das raças inferiores", essas expedições submeteram ao cárcere, maus tratos e morte, mulheres ainda crianças, que sequestravam no continente africano. Ainda mais, nessas pesquisas produziam-se desenhos, moldagens e fotografias dos corpos das mulheres africanas sequestradas, com o objetivo de localizar o primitivismo morfológico e buscar equivalentes nas culturas por elas praticadas. ${ }^{18}$
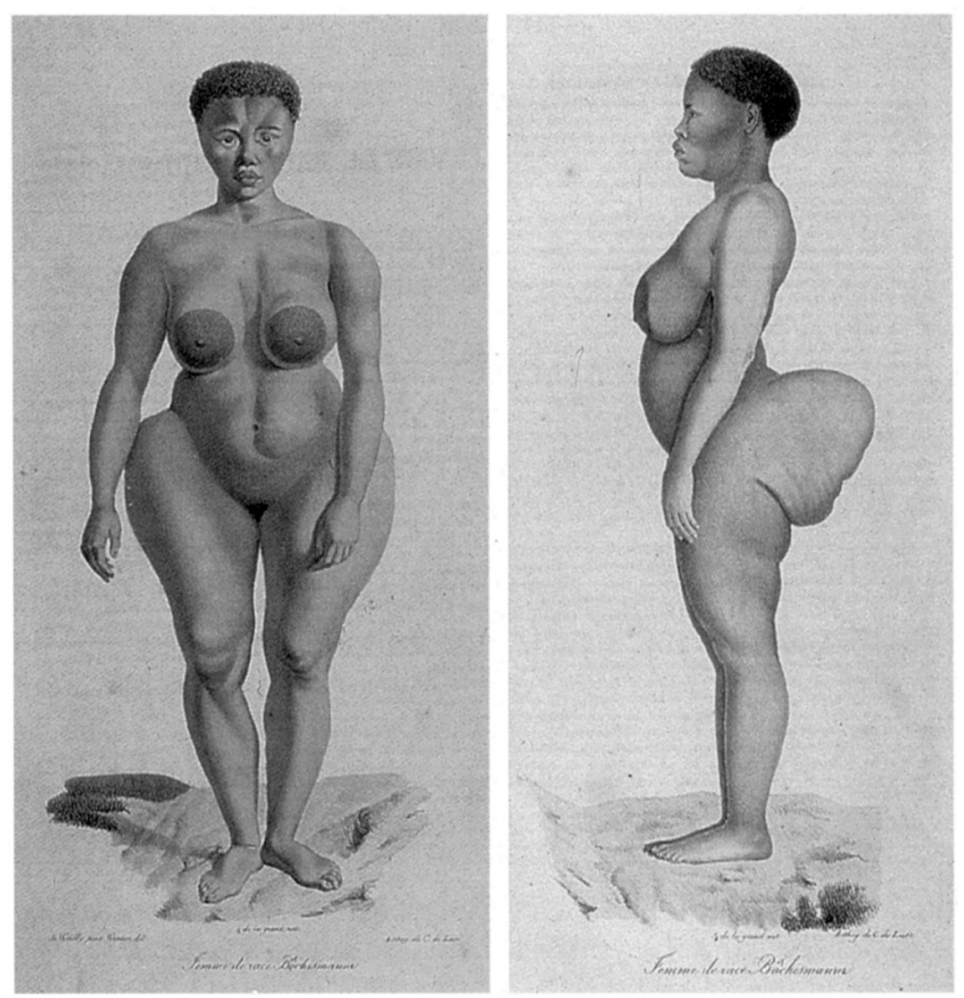

Étienne Geoffroy Saint-Hilaire. A História natural dos mamíferos com figuras originais coloridas, desenhadas a partir de animais vivos, Paris, A. Belin, 1824, tomo 1, pranchas 1 e 2; Paris, Muséum d'Histoire Naturelle, biblioteca. ${ }^{19}$

Os caracteres físicos da "Vênus Hottentote" foram estereotipados e serviram de modelo para a criação de um paradigma. A infeliz comparação feita por Querino das "nádegas salientes" das jejes com o corpo da "Vênus Hottentote" demonstra o desconhecimento das implicações desse estereótipo sobre as mulheres africanas. Por outra parte, a foto da mulher jeje (Est. X) apresentada por Querino em nada se aproxima da representação feita da "hottentote". A “jeje" foi retratada trajando uma elegante camisa, sob um pano da costa branco, uma longa saia com motivos geométricos, tecidos e as jóias

${ }^{17}$ COMAROFF, op.cit. p. 98-99

18 Dubow, Saul, 1995, Illicit union: Scientific racism in South Africa. Johannesburg: Witwatersrand University Press. SAMAIN Étienne. Quando a fotografia (já) fazia os antropólogos sonharem: O jornal La Lumière (1851-1860) Revista de Antropologia, São Paulo, USP, 2001, v. 44 no 2. COMAROFF, op.cit. p. 117-19

19 SAMAIN, op.cit. 
de crioula, estética própria das mulheres africanas na Bahia, que formavam um mercado consumidor exclusivo para esses produtos.

Os homens também foram classificados por Querino, de acordo com a adaptação a trabalhos específicos, traços de personalidade, costumes e capacidade intelectual. Foram destacadas dez etnias: mina, iorubá, egbá, quêto, angola, igê-chá, congo, nagô, jeje e efon. Somente três delas são representadas por fotografias: os jejes, iorubá e os igê-chá. Como escreve Querino:

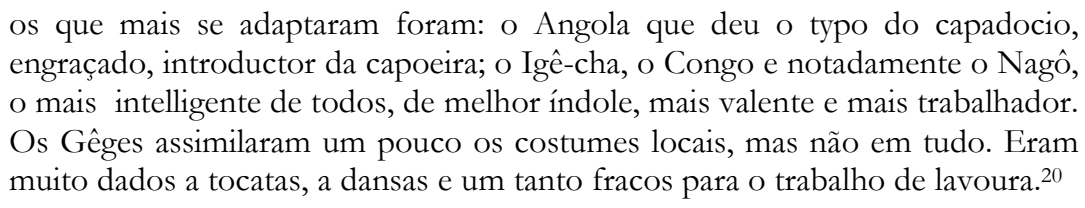

Observam-se, aqui, complicações que não se sabe como Querino resolveu. Diferentemente das legendas, onde o termo iorubá denominou uma etnia específica, no trecho acima, o termo generalizante nagô, foi usado e, como já foi dito, incluía geralmente os ketu, igê-chá, oondó, egbá, efon e todos os demais falantes de iorubá. Além disso, desconhece-se como ele chegou ao exercício da descrição acima. Um outro aspecto observado refere-se aos bantu (plural de mtu, pessoa). Querino reconhece pessoas do Congo e de Angola na etnografia, mas não os representa na fotografia. Essa ausência pode ser explicada pelo menor número dessa etnia nos últimos anos, anteriores à extinção do tráfico baiano.

Segundo João Reis, a partir de 1819-1820, os nomes de nação foram melhor discriminados na documentação, o que permitiu constatar que "os grupos mais numerosos embarcados nos portos de Benin (nagôs, haussás, jejes e tapas) representavam quase 54\% dos escravos da Cidade da Bahia nascidos na África", ao passo que a população bantu declinou, de 31,4\% em 1819-20 para 27,2\% em 1835. ${ }^{21}$ Para o período posterior, Maria Inês Oliveira, com base em 1.760 inventários entre os anos de 1811-1888, informa que 57,4\% dos inventariados eram nascidos na África. Desses, 78,4\% vinham da costa ocidental, antigo Daomé, território da atual Nigéria e República do Benin. Nos portos dessa região, embarcavam nações aqui designadas como nagôs (que também se definiam como ijexás,

20 Consideramos aqui os atributos do nagô com a identificação da fotografia do Iorubá, pois, no entendimento de Querino, o termo nagô abrangia as etnias “mina, iorubá, ige-chá, ige-bú, efon, otá, egbá, devido a grande extensão de território que comprehende as terras das Costa dos Escravos. As tribus egbá e ioruba, as mais distinctas, eram consideradas primitivas". Querino, op.cit. p. 14 nota 1.

${ }^{21}$ REIS, João José. Rebelião escrava no Brasil. A história do levante dos Malês em 1835. São Paulo, Cia das Letras, 2003, p. 308. 
ijebus de Oyó e os de Ketu), jejes, hausssas, minas, tapas, bornos. ${ }^{22}$ Os dados presentes nos inventários consultados por Oliveira corroboram os dados de Verger, que dividiu o tráfico em direção à Bahia, de acordo com os portos de procedência: Guiné, durante a segunda metade do século XVI; Angola e Congo, no século XVII; Costa da Mina, século XVIII e Baia de Benin a partir de 1770 até o período do tráfico ilegal. ${ }^{23}$ Contudo, isso não significa que a população e a cultura bantu não estivessem presentes na Bahia. O fato de Querino referir-se a eles na etnografia é demonstração disso.

Outro uso da fotografia como suporte etnográfico foi a série em que Querino tematizou o candomblé.

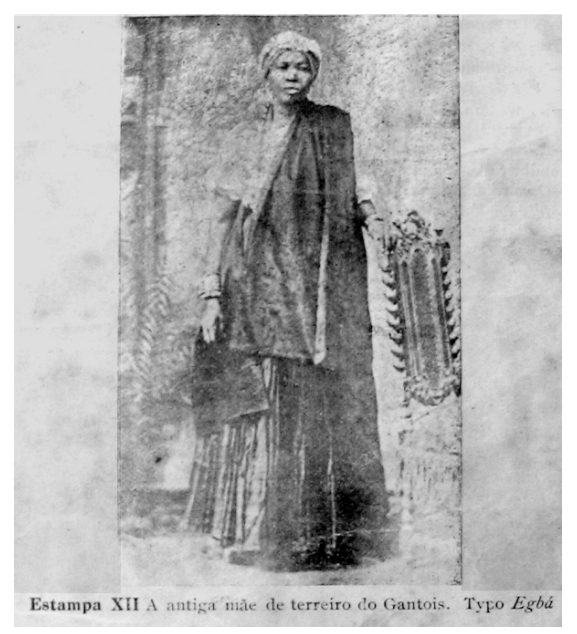

Estampa XII A antiga mãe de terreiro do Gantois Typo Egbà

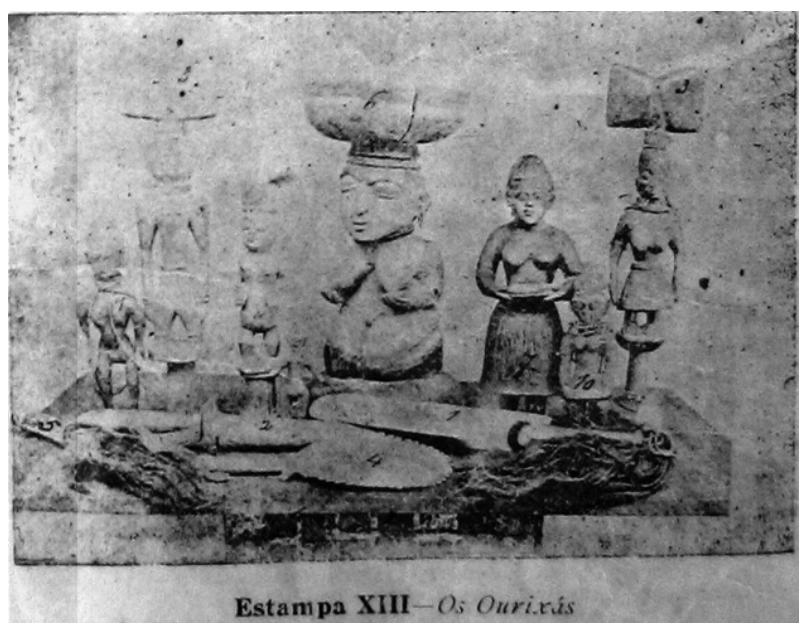

Estampa XIII Os orixàs

22 OLIVEIRA, Maria Inês Cortes. Quem eram os "negros da Guiné”? “A origem dos africanos na Bahia". Afro-Ásia, n. 19/20 (1997), 37-74. "Viver e morrer no meio dos seus: nações e comunidades africanas na Bahia do século XIX”. Revista USP, n. 28 (1995/96) p. 174-193

23 VERGER, Pierre. Fluxo e refluxo do tráfico de escravos entre o Golfo do Benin e a Babia de Todos os Santos, dos séculos XVII a XIX. Salvador, Corrupio, 2002. 


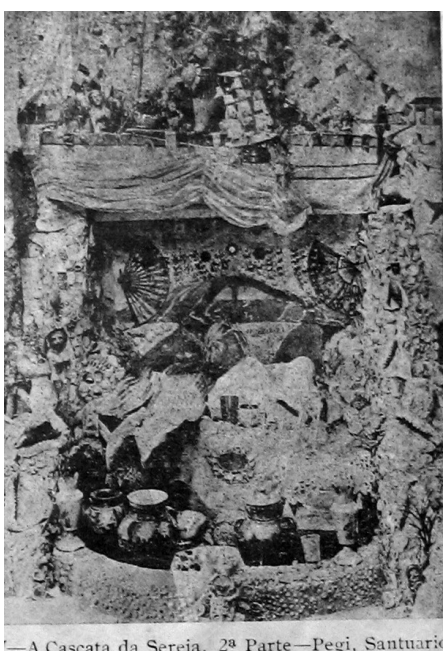

Estampa XIV Cascata da Sereia. $2^{a}$ parte

Pegi, Santuário, Candomblé do Gantois

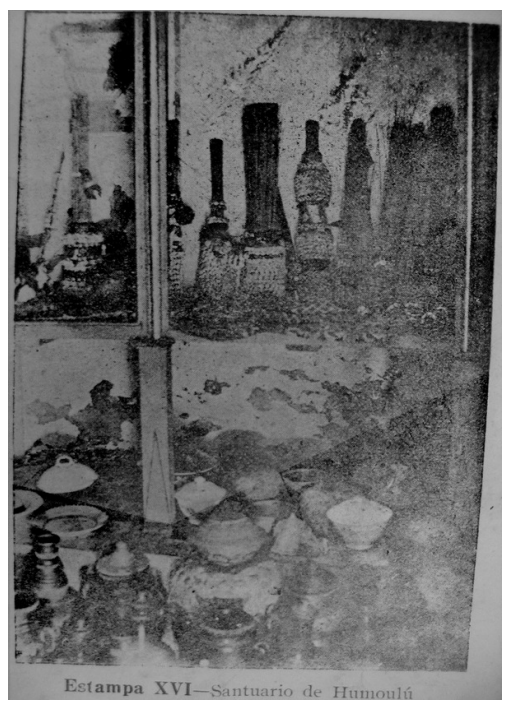

Estampa XVI Santuário de Homolu Ochóssi

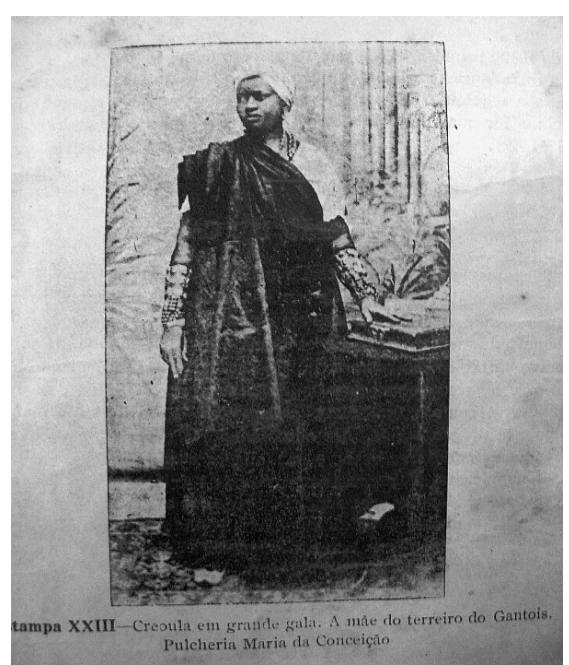

Estampa XXIII Creoula em grande gala.

A mãe do terreiro do Gantois Pulchéria Maria da Conceição

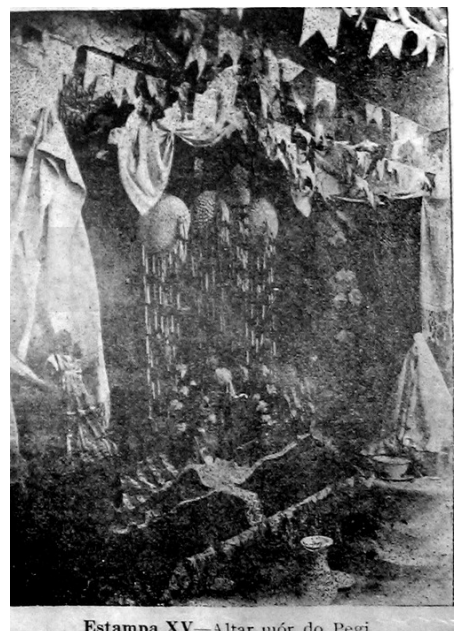

Estampa XV-Altar mór do Pegi

Estampa XV Altar mor

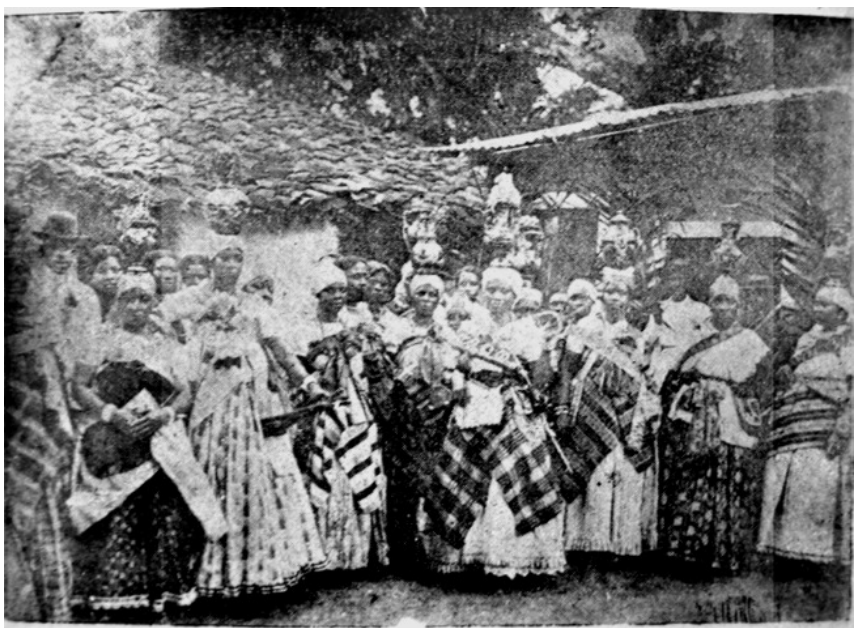

Estampa XVII - A dansa das quartinhas. Festa de Oehóssi

Estampa XVII A dansa das quartinhas. Festa de

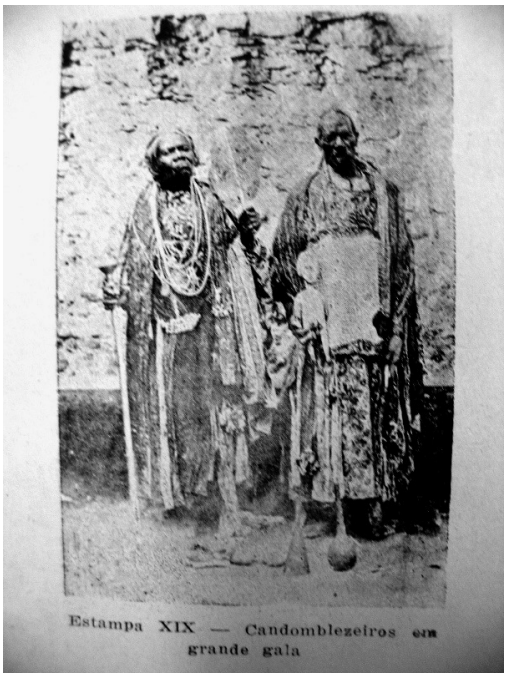

Estampa XIX Candomblezeiros em grande gala 
Em particular, o uso que Querino fez dos retratos das mães de santo do Terreiro do Gantois se afasta da representação estereotipada daquelas fotografias de tipos humanos. Pulchéria Maria da Conceição (Est. XXIII) foi individualiza com nome e cargo na religião que professava. Pulchéria foi a segunda mãe de santo do Terreiro do Gantois, filha da fundadora, Maria Júlia da Conceição Nazaré, (Est. XII) que aparece como “typo Egba” e identificada como "a antiga mãe de terreiro do Gantois". Este dado sugere que a terminologia de "typo" para Querino estava associada ao conceito de raças puras africanas, enquanto Pulchéria, "creoula em traje de gala", nascida na Bahia, não podia ser qualificada como representante de uma sociedade africana específica.

Outra fotografia no marco do candomblé representa a "dança das quartinhas, Festa de Ochóssi” (Est.XVII). Esta fotografia acompanha o trecho do ensaio onde Querino explica a cerimônia de iniciação de um ogan, cargo religioso destinado aos homens, cujo protagonista "perante o altar de S. Jorge (Ochóssi), rodeado de muita gente, é apresentado pela mãe do terreiro, que profere algumas palavras em linguagem africana e passa-lhe um panno da Costa pelos ombros". Passados seis meses, realiza-se a confirmação do ogan, que oferece uma festa que se prolonga por vários dias. A cerimônia "dança das quartinhas" foi instituída pela Ialorixá Pulquéria (1840-1918) em reverencia a seu orixá Oxossi. ${ }^{24}$

Encontrei uma cópia da fotografia utilizada por Querino no arquivo do Instituto Feminino Henriqueta Catarino. A cópia do arquivo foi ampliada em papel fotográfico, sem referência ao fotógrafo e sem legenda. Sobre a imagem, consta a anotação: "sem direito a reproduzir". No verso, uma dedicatória de Alberto M. M. Catharino para o Instituto Feminino datada de 13 de agosto de 1934, dezoito anos após a publicação de Querino. ${ }^{25}$

${ }^{24}$ NÓBREGA Cida e ECHEVERRIA Regina. Mãe Menininha do Gantois, Uma biografia Salvador: Corrupio; Rio de Janeiro: Ediouro, 2006.

${ }_{25}$ Acervo fotográfico do Instituto Feminino Henriqueta Catarino, arquivo de aço, envelopes pequenos, foto nํำ 99. 


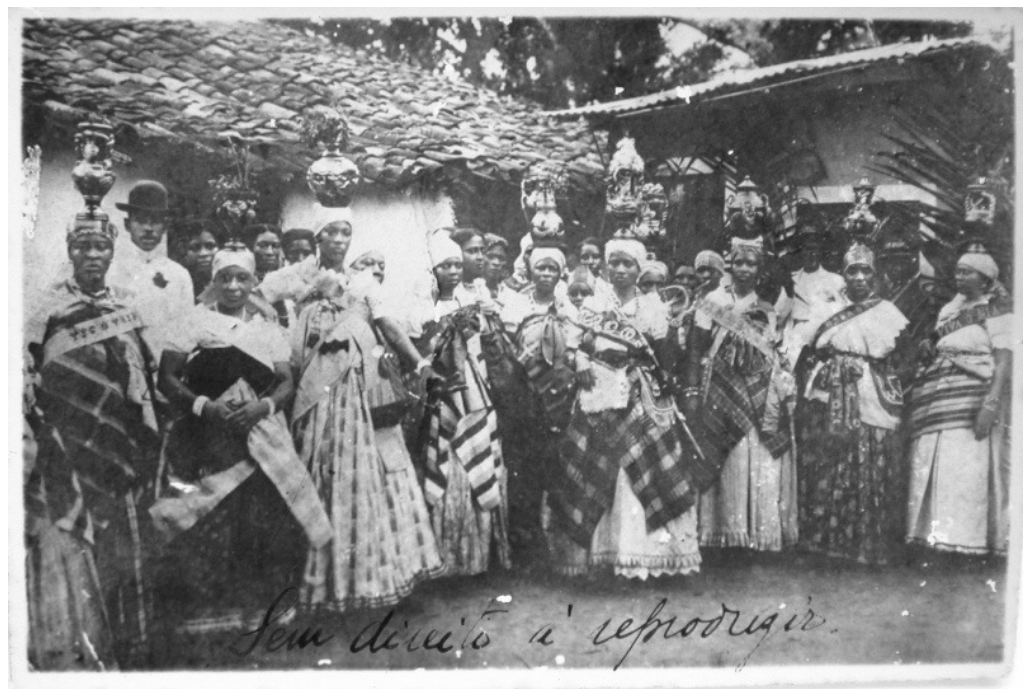

(fig. 1) Fotógrafo não identificado, Bahia, Terreiro do Gantois, s.d., papel fotográfico, acervo IFHC.

Esses dados indicam tratar-se de uma fotografia particular e sugere que as pessoas fotografadas ou sua liderança, no caso, a mãe de santo do Gantois, proibiam que a vida privada do seu terreiro fosse comercializada como cartão postal. O impedimento para reproduzir esta fotografia não se estendeu ao ensaio de Querino, que não somente reproduziu, mas descreveu a cerimônia. Neste contexto o estudo de Querino poderia ser uma estratégia conjunta entre o pesquisador e o Terreiro, para que o autor divulgasse o refinamento cultural dessa expressão religiosa, de modo a combater a perseguição policial que sofreram os Terreiros de Candomblé nas primeiras décadas do século XX. ${ }^{26}$

A série de fotografias que tematizou o candomblé e suas festividades foi, na sua maioria, realizada pela Photographia Diamantina. No livro de Sofia Olszewski, quem teve acesso aos originais, consta o endereço do estabelecimento sito à Rua Dr. Seabra, 211, informação que frequentemente aparecia no verso do cartão. ${ }^{27}$ Localizado na freguesia de Nossa Senhora do Passo, área de comércio popular de Salvador, a Photographia Diamantina estava afastada do circuito comercial dos outros ateliês existentes na cidade, situados nas freguesias da Sé e São Pedro. Nos almanaques e periódicos da época, veículo de publicidade dos estabelecimentos fotográficos, não consta a Diamantina; tampouco nos livros de impostos ou licença para comércio. O único registro da existência deste estabelecimento fotográfico está na própria fotografia, associada ao candomblé, seus objetos sagrados e autoridades religiosas. ${ }^{28}$

\footnotetext{
${ }^{26}$ Sobre a perseguição aos terreiros de Candomblé na Bahia ver Luis Nicolau Pares, A formação do Candomblé. História e Ritual da nação jeje na Babia. Campinas, Unicamp, 2006. CASTILLO, op. cit.

${ }^{27}$ OLSZEWSKI FILHA, Sofia. A fotografia e o negro na cidade do Salvador. 1840-1914. Salvador, EGBA, 1989, p.108-109, 111.

${ }^{28}$ VASCONCELLOS, Christiane Silva. "O circuito social da Fotografia da Gente Negra. Salvador, 1860-1916". Dissertação de Mestrado, UFBA, 2006. cap. 1.
} 
A última série da coleção de Querino trata de um setor laboral da sociedade baiana oitocentista, os carregadores do canto, as ganhadeiras e ganhadores, os quais Querino analisa no tópico denominado "A Industria". Segundo ele, "os africanos, depois de libertos, não possuindo officio e não querendo entregar-se aos trabalhos de lavoura, que haviam deixado, faziam-se ganhadores," atividade mais rentável dos serviços urbanos.

Para representá-los, Querino utilizou o famoso cartão postal “Grupo de Carregadores Africanos - Bahia - Brasil” impresso por J. Mello editor, no final do século XIX.

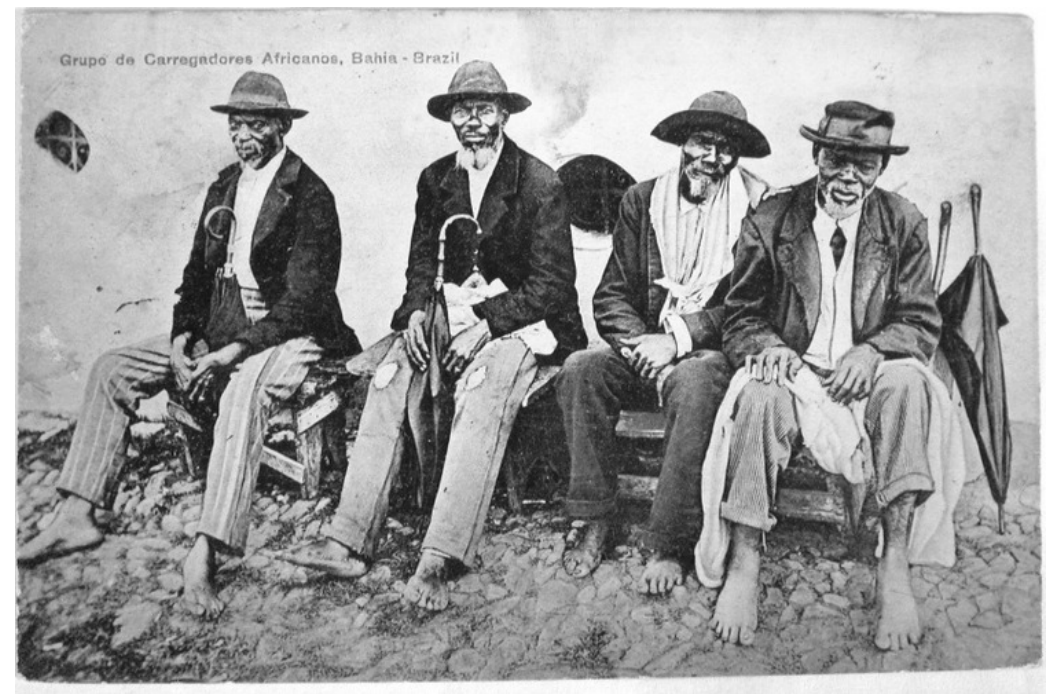

Editor, c.1900, Coleção RBC, acervo APM

(fig. 2) Grupo de carregadores africanos, Bahia, Brasil, J. Mello

Na legenda, Querino identificou a imagem como "Ganhadores no canto".

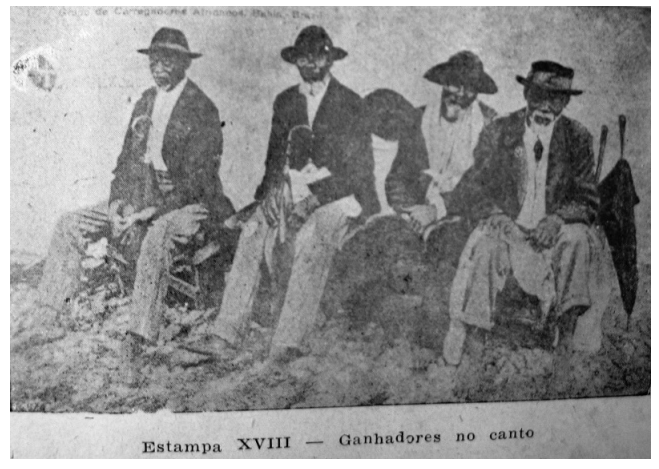

Estampa XVIII Ganhadores no Canto.

Segundo Querino, canto era o local onde se reuniam os trabalhadores africanos, especializados no transporte de mercadorias e pessoas que circulavam na cidade. Organizados etnicamente, os cantos estavam distribuídos pela cidade, e ali os trabalhadores, enquanto aguardavam alguma carga, realizavam distintas atividades como: 
"preparavam rozarios de coquilhos com borla de retroz de cores, pulseiras de couro, enfeitadas de búzios e outras de marroquim oleado; fabricavam correntes de arame para prender papagaios, esteiras e chapéus de palha de ouricori, e bem assim vassouras de piassava; lavavam chapéus de Chile e de outra palha qualquer, e consertavam chapéus de sol". Também nos cantos eram tratados os panos da costa que chegavam da África crespos e duros. Através de uma técnica que utilizava tora de madeira em forma de cilindro, os tecidos eram lustrados e amaciados. Aqueles já usados eram renovados por tingimentos. Nos cantos, os trabalhadores também produziam esculturas, "mostravam ainda tendências para as artes liberaes, esculpturando os symbolos feiticistas de sua seita, tão aperfeiçoados quanto possível" 29

A descrição etnográfica realizada por Querino demonstra seu conhecimento e proximidade com o contexto estudado, ou seja, o dia-a-dia dos cantos, uma unidade produtiva, de relações sociais e entretenimento. Querino descreve, ali, um jogo de tradição africana chamado "A-i-û que consistia num pedaço de taboa, com doze partes côncavas, onde collocavam e retiravam os a-i-ûu-s, pequenos fructos cor de chumbo, originários da África e de forte consistência". ${ }^{30}$ Descreveu, ainda, uma cerimônia, que ele provavelmente testemunhou, de posse do capitão de canto. O estudo de Querino, ao lado do pouco que Nina Rodrigues escreveu, representa hoje fonte para as pesquisas sobre o assunto. ${ }^{31}$

As fotografias identificadas por Querino como "representante da tribo ige-cha" (Est. III) e "representante da tribo iorubá" (Est. IV) assim como os "ganhadores do canto" (Est. XVIII) foram localizadas nos arquivos da cidade de Salvador, no suporte de bilhete postal, legendados como "ganhador africano".

${ }^{29}$ QUERINO, A raça africana, op. cit p.46

30 QUERINO, op. cit.

31 REIS, "De olho no Canto", p. 199-242; RODRIGUES, Nina, Africanos no Brasil, São Paulo, Cia Editora Nacional, 1977, Wilson Santos, Negros contra a ordem: Resistências e práticas negras de territorialização cultural no espaço da exclusão social - Salvador-BA (1850-1888), Tese doutorado, PUC-SP, 2000. 


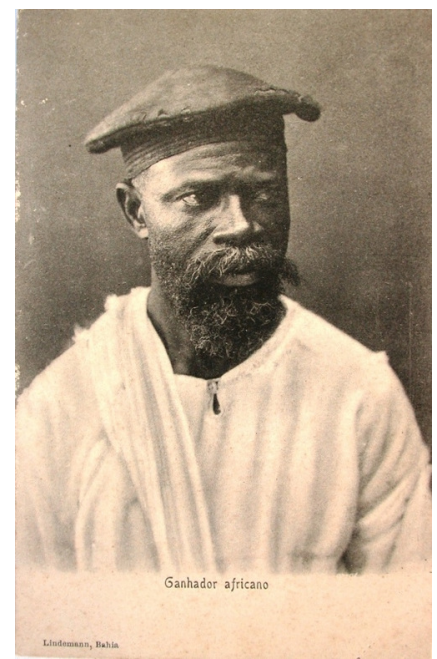

(fig. 3) Rodolpho Lindemann, Bahia, Ganhador africano, bilhete postal,

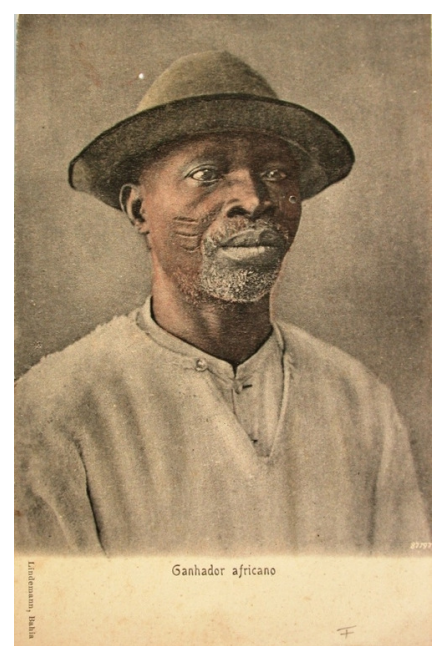

(fig. 4) Rodolpho Lindemann, Bahia, Ganhador africano, bilhete postal,

Fotografia e legenda dos retratos foram feitas pelo fotógrafo alemão Rodolph Lindemann, provavelmente entre os anos 1890 e 1900, no seu estúdio no Largo do Theatro, em Salvador. Foram identificadas como "Ganhador Africano" e faziam parte de uma série maior que vinculava o retratado a um ofício: caixinheira, ama de leite, vendedora de frutas, ganhadeira, lavadeira e ganhador africano. As cópias feitas no suporte do bilhete postal, pertencentes ao acervo do Arquivo Público Municipal, apresentam um colorido artificial. $^{32}$

Particularmente, o "Representante da Tribu Iorubá” em Querino e o "Ganhador Africano" em Lindemann são a mesma fotografia. A mesma imagem ainda foi utilizada como vinheta, na composição de um bilhete postal. (f.4), onde consta uma dedicatória que identificou o retratado como "Ganhador/Portefaix".

Tem-se aqui um exemplo dos distintos sentidos dados a uma só imagem. $\mathrm{Na}$ legenda de Lindemann "ganhador africano", referência laboral e racial, na generalidade dos “typos da rua”. Em Querino adquire o status de documento etnográfico e, como tal, serviu para explicar diferenças entre pessoas de uma etnia africana particular. Na dedicatória, foi identificada como representativo trabalhador da Bahia, "ganhador portefaix (carregador).

\footnotetext{
${ }^{32}$ VASCONCELLOS, op. cit. .p.30-52
} 


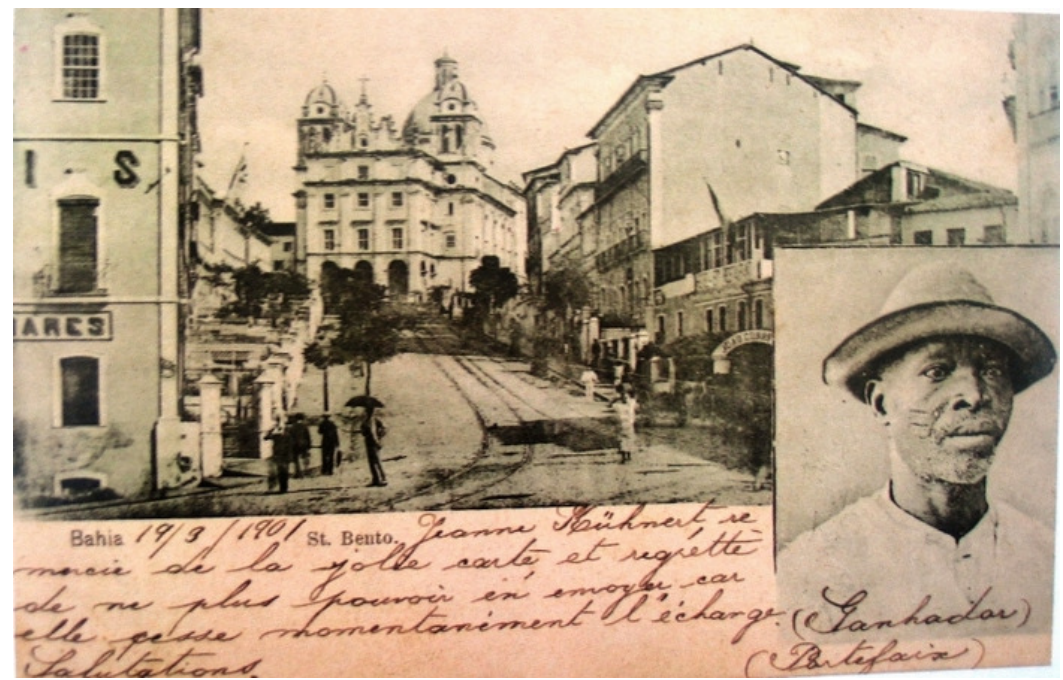

(fig. 5) Clichê R. Lindemann, c.d. Bahia St. Bento, d.1901, coleção E. Hackler, VIANNA, 2004, 155.

"19/9/1901 Jeanne Kuhnert remercie de la jolie carte et regrette de ne plus pouvoir en envoyer car elle cesse momentainement l'echarge. Salutations." (Ganhador) (Portefaix)

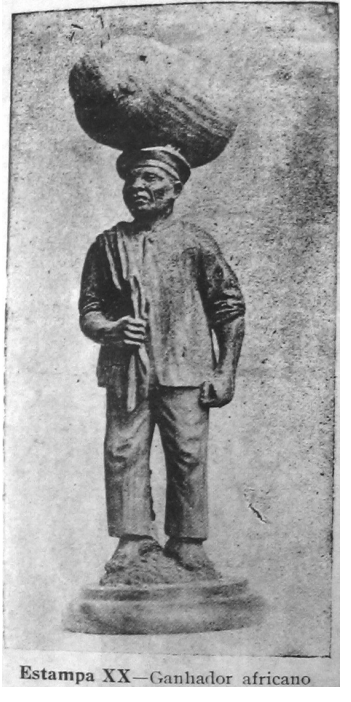

Estampa XX Ganhador Africano

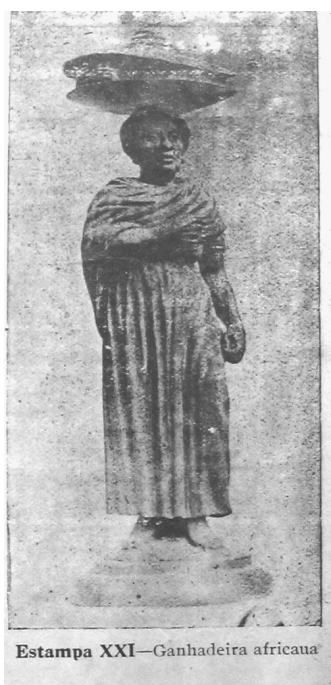

Estampa XXI Ganhadeira Africana

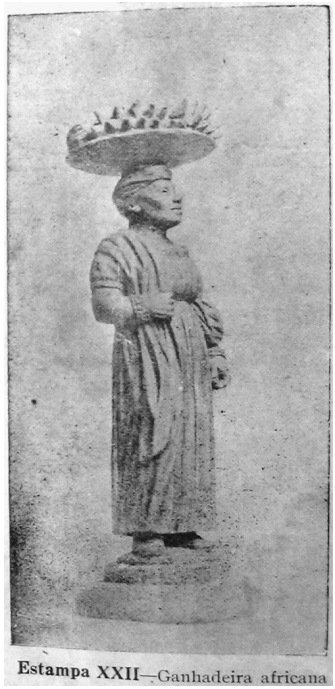

Estampa XXII Ganhadeira Africana

Ainda acerca da temática ganhadores e ganhadeiras, Querino adicionou à sua coleção fotografias de esculturas, as quais ele identificou como ganhador africano e ganhadeira africana. Na obra "Artistas Bahianos", publicada em 1909, esculturas semelhantes foram atribuídas a Erotides América de Araújo Lopes, com a legenda de “Typos da Rua (Mercadores ambulantes) feitas em casca de cajazeira. ${ }^{33}$

33 QUERINO, Manoel Raymundo. Artistas Babianos. Rio de Janeiro, Imprensa Nacional, 1909 
A técnica etnográfica, utilizada por Querino para investigação da cultura africana na Bahia, foi explorada no ensaio para demonstrar a riqueza religiosa, laboral, tecnológica, artística e de entretenimento, desenvolvida pelos africanos na Bahia. Como abordagem de pesquisa, a etnografia empreendia por Querino trouxe contribuições inéditas para o campo dos estudos acerca da África e dos africanos na diáspora americana. No ensaio, a descrição minuciosa dos dados indica a preocupação do autor em introduzir os africanos como agentes sociais que tiveram uma participação dinâmica e modificadora das estruturas sociais escravistas.

Quanto à qualidade de impressão das fotografias da coleção, pode-se observar que a incipiente técnica do clichê, usada na época, comprometeu a nitidez das imagens na publicação da separata do ensaio e nos Anais do Congresso, ambos em 1917. Estas mesmas imagens foram reproduzidas na coletânea organizada em 1938 por Arthur Ramos. ${ }^{34}$ Porém, nas publicações de 1955, da Livraria Progresso, e, na edição ampliada e comentada publicada pela Fundação Joaquim Nabuco em 1988, as fotografias foram suprimidas do texto. À exceção de quatro fotografias, e isso é importante em termos do valor da fonte, essas publicações são as únicas evidências que se tem tanto da existência dessas fotografias, bem como uso feito das mesmas.

No final da década de 1980, Sofia Olszewiski pesquisou as fotografias de pessoas negras em Salvador e escreveu que "nas fotografias de negros da coleção do Instituto Histórico constam anotações no verso contendo nomes das possíveis nações a que pertenciam os retratados. Não se sabe o autor dessas anotações". ${ }^{35}$ As imagens às quais a autora se refere foram publicadas no seu livro A fotografia e o negro na cidade de Salvador, 1840 1914 e também estão presentes no ensaio de Querino, com as mesmas anotações destacadas por Olszewiski, de modo que Querino certamente é o autor das anotações e da coleção de fotografias. Ele era sócio e frequentador do Instituto Geográfico e Histórico da Bahia desde 1894 e ali teve a oportunidade de desenvolver sua produção intelectual. Além disso, foi o IGHBa que coordenou o $5^{0}$ Congresso Brasileiro de Geografia, para o qual ele destinou seu ensaio, acompanhado das fotos. Infelizmente, não foi encontrada, no acervo

\footnotetext{
34 Annaes do 50 Congresso Brazileiro de Geografia, 1916, volume I. A Raça africana e seus costumes na Babia, Bahia, Imprensa Official do estado, 1917. Em 1938 foi inserido na publicação Costumes africanos no Brasil, organizada e prefaciada por Artur Ramos. Uma nova edição foi organizada em 1988, por ocasião das comemorações do centenário da Abolição. O prefácio é de Raul Lody e a apresentação, de Thales de Azevedo, $2^{a}$ ed. revista e ampliada, Recife, FUNDAJ/Editora Massangana/FUNARTE, 1988. Nessas edições, foram reunidos os seguintes títulos: 1. A raça africana e seus costumes na Bahia - com apêndice: Candomblé de caboclo; 2. O colono preto como fator da civilização brasileira; 3. A arte culinária na Bahia; 4. Notas de folclore negro (excertos de $A$ Babia de outrora). A raça africana teve a sua $2^{a}$ edição.

35 OLSZEWSKI FILHA, op.cit. p.70.
} 
do Instituto, nenhuma destas fotografias. Desapareceram na vastidão do descaso que assombra os arquivos públicos no Brasil.

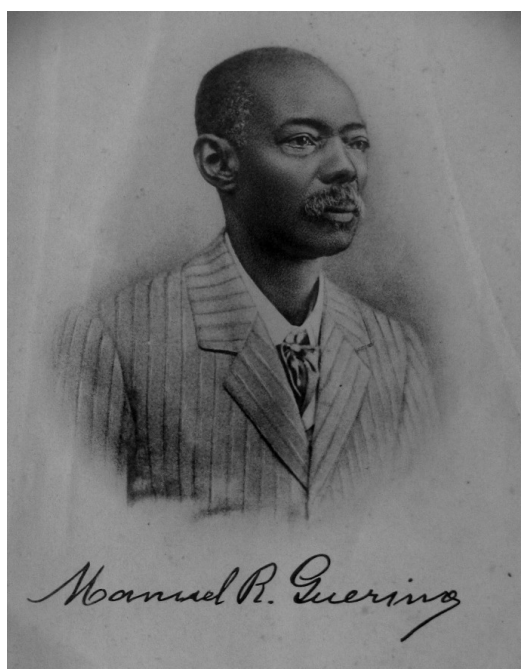

Manuel Raymundo Querino nasceu em Santo Amaro, Bahia, em 28 de julho de 1851. Aos quatro anos de idade perdeu os pais, vítimas da epidemia de cólera que assolou a região do Recôncavo baiano naquela época. ${ }^{36}$ Querino era mestiço, mas não se sabe se seus pais também o eram, ou se um deles era negro, pardo ou africano, e o outro branco, se eram escravos, libertos ou livres.

(fig.6) Manuel Querino, 1911

In. Artistas Bahianos. Indicações Biográphicas. Bahia, Officinas da Empreza “A Bahia”, 2ª edição, 1911.

$\mathrm{Na}$ capital baiana, Querino aprendeu o ofício de pintor-decorador e, aos 17 anos, foi recrutado para a Guerra do Paraguai, onde serviu como escrevente até o final do conflito. De volta a Salvador, no ano de 1871, trabalhou como pintor e foi aluno do recémcriado Liceu de Artes e Ofícios da Bahia, onde estudou português, francês, desenho e pintura. Mais tarde, tornou-se professor de Desenho Industrial e Geométrico no mesmo Liceu. Foi também professor da mesma disciplina no Colégio dos Órfãos de São Joaquim e funcionário da Secretaria da Agricultura. Participou da fundação do Partido Operário da Bahia, em 1890, e foi eleito vereador, mandato que exerceu entre 1897-1899. Ao fim dessa atuação na política, passou a se dedicar exclusivamente ao magistério e à produção intelectual, ligando-se ao Instituto Geográfico e Histórico da Bahia (IGHBa). ${ }^{37}$

Querino testemunhou a difícil integração da população negra, egressa da escravidão, no novo regime republicano. Ele mesmo, na condição de mestiço, órfão e pobre, sofreu com a discriminação racial vigente em seu tempo. Nos seus escritos, assumiu-se como um crítico da escravidão e da república, em defesa da classe operária nacional e do legado africano na cultura baiana. Foi autor dos seguintes trabalhos: Desenho linear das classes elementares (1903), As artes na Babia (1909, 1913), Artistas baianos (1909, 1911), Elementos do desenho geométrico (1911), Bailes pastoris (1914), A Babia de outrora, vultos e fatos populares (1916, 1922, 1946, 1954), A raça africana e seus costumes na Babia (1916, 1917, 1955),

36 Sobre a vida e obra de Querino, consultar as biógrafas LEAL, Maria da Graças. Manuel Querino: entre letras e lutas. Babia 1851-1923. Tese de Doutorado, Puc, São Paulo, 2004, GLEDHILL, Sabrina. Manuel Raimundo Querino. In: Jaime Nascimento; Hugo Gama. (Org.). Manuel R. Querino Seus Artigos na Revista do Instituto Geográfico e Histórico da Bahia. Salvador: Instituto Geográfico e Histórico da Bahia - IGHB, 2009, p. 225238.

${ }^{37}$ SODRÉ, Jaime. Um herói de raça e classe, Salvador, sem editora, 2001, p.89-93. Também LEAL, op. cit 
O colono preto como fator de civilização brasileira (1918) e $A$ arte culinária na Babia (1928, 1951). Faleceu em Salvador em 1923 sem o reconhecimento pelos seus trabalhos intelectuais.

Tal como argumenta Antônio Sérgio Guimarães, nesse período os intelectuais negros eram considerados antes folcloristas que científicos. Prioritariamente eram valorizados pelo acesso às fontes orais e não por suas formulações teóricas:

\begin{abstract}
negros leigos e antropólogos autodidatas, reconhecidos como folcloristas ou jornalistas, que tomaram a 'cultura' ou os 'costumes' africanos como tema de seus trabalhos. [...] Nunca foram reconhecidos como "homens de ciência" ou cientistas [...] a legitimidade baseava-se quase exclusivamente no acesso privilegiado que tinham às fontes e às pessoas sobre as quais escreviam (artesãos, festeiros populares, africanos, pais e mães de santo). Em grande parte o reconhecimento social desses intelectuais negros deve-se ao trabalho de outros intelectuais de maior prestígio, quase sempre brancos, que entre 1930 e 1950 mudam o foco de suas preocupações da cultura européia e lusitana para a cultura africana ou mestiça popular, principalmente para a religiosidade e a culinária afrobrasileira. ${ }^{38}$
\end{abstract}

Manuel Querino foi um desses intelectuais negligenciados pela academia brasileira, não obstante o pioneirismo de suas proposições tanto no campo da história da arte baiana ${ }^{39}$ como nas teorias sobre a história e a cultura afro-brasileira. $\mathrm{Na}$ Bahia, nos primeiros anos da República, uns poucos descendentes de africanos ingressaram nos setores intelectuais, profissionais liberais, servidores públicos e militares, cujo baixo número evidencia a dificuldade deste grupo, ainda que mestiços, em ingressar nos círculos de tradição européia. Dentre os mestiços contemporâneos de Querino que entraram nesse lugar, podem ser citados Francisco Álvares dos Santos (professor da Faculdade de Medicina), Luiz Gama, André Rebouças, Luiz Anselmo da Fonseca, Virgílio Climaco Damásio, César Zama, Abílio César Borges (Barão de Macaúbas), Teodoro Sampaio, Antônio Carneiro da Rocha, João Florêncio Gomes, Ramos de Queiroz e Braz do Amaral. ${ }^{40}$

No $5^{0}$ Congresso presidido pelo engenheiro negro Theodoro Sampaio, o ensaio de Manuel Querino foi o único estudo de conteúdo histórico e etnográfico entre os 111 trabalhos apresentados, 104 exposições cartográficas e 1057 inscrições. ${ }^{41}$ Nos Congressos de Geografia eram privilegiados estudos de toponímia e memória histórica dos municípios, cartografia, hidrografia, climatologia, sertão, secas e riquezas naturais. Cada trabalho destacava a metodologia científica aplicada na instituição a que estava vinculado seu autor, porém, para além dos estudiosos, a apresentação dos trabalhos era feita para governantes

\footnotetext{
${ }^{38}$ GUIMARÃES, Antônio Sérgio A. Manuel Querino e a formação do pensamento negro no Brasil entre 1890 e 1916. ${ }^{39}$ NUNES, Eliane. Manuel Raymundo Querino: o primeiro historiador da arte baiana. Revista Obun, ano 3, n. 3, p. 237-261, set. 2007

40 LEAL, p.96.

41 Anaes do V Congresso de Geografia, Salvador, Imprensa Oficial, 1916. LEAL, op.cit. p.317, nota 150.
} 
municipais, estaduais e federais. Isto indica que o ambiente desses congressos não tinha características exclusivamente acadêmicas. ${ }^{42}$ No mesmo ano do congresso, Querino foi “inesperadamente" afastado das funções que ocupava desde 1893 na Secretaria de Obras. ${ }^{43}$ Devido à proximidade dos dois eventos e a restrita participação permitida aos acadêmicos afrodescendentes, é possível que o afastamento do cargo estivesse relacionado com os posicionamentos teóricos de Querino. Neste mesmo ano, Manoel Querino publicou $A$ Babia de Outrora - vultos e fatos populares, coletânea de artigos publicados nos jornais locais e na Revista do IGHBa e, dois anos depois, publicou $O$ colono preto como factor da civilização brazileira. Manuel Querino usou a escrita para minar o universo racista que tentou de várias maneiras silenciá-lo. Paradoxalmente a historiografia que, por muito tempo, o manteve esquecido ou depreciado agora utiliza sua vida e obra como fonte histórica.

\section{Referencias Bibliográficas}

1. ALINDER, Jasmine. La retórica de la desigualdad: Las fotografias de los escravos del Brasil em el siglo XIX. In História y memória: sociedad, cultura y vida cotidiana en Cuba 1878-1917, La Habana, Centro de Investigación y Desarrollo de la Cultura Cubana Juá Marinello. 2003.

2. ANDREWS George Reid, Negros e brancos em São Paulo (1888-1988), Bauru, Editora do Sagrado Coração, 1998

3. CASTILLO, Lisa Earl; PARES, Luis Nicolau. "Marcelina da Silva e seu mundo: novos dados para uma historiografia do candomblé ketu "Afro-Asia, n.36, 2007

4. COMOAROFF, Jean e John. Of revelation and revolution: Christianity, Colonialism and Consciousness in South Africa, Chicago, The University of Chicago Press, 1991, vol. 1.

5. DUBOW, Saul, 1995, Illicit union: Scientific racism in South Africa. Johannesburg: Witwatersrand University Press.

6. EDWARDS, Elizabeth. "Antropologia e Fotografia" Cadernos de Antropologia e Imagem 2. Rio de Janeiro, 1996

7. FABIAN, Johannes. Time and the other: how anthropology makes its objects, New York, Columbia University Press, 1983.

8. GLEDHILL, Sabrina. "Manuel Raimundo Querino". In: NASCIMENTO, Jaime; GAMA, Hugo (Orgs.). Manuel Raimundo Querino. Seus artigos na Revista do Instituto Geográfico e Histórico da Bahia. Salvador: Instituto Geográfico e Histórico da Bahia - IGHB, 2009.

9. KOSSOY Boris. Dicionário histórico-fotográfico brasileiro: fotógrafos e ofícios da fotografia no Brasil (1833-1910). São Paulo, Instituto Moreira Sales, 2002.

10. LEAL, Maria da Graças. Manuel Querino: entre letras e lutas. Babia 1851-1923. Tese de Doutorado, Pontifícia Universidade Católica, São Paulo, 2004.

11. MATORY, J. Lorand. The english professors of Brazil: On the diasporic roots of tuhe Yorubá Nation. Comparative Studies in Society and History, n. 1 vol. 41 Cambridge

42 EVANGELISTA, Hélio de Araújo. Congressos Brasileiros de Geografia. Disponível em: http:// feth.ggfig...br/Congresso.htm, acessado em 10/11/2005.

${ }^{43}$ LEAL, op.cit., p. 270 
12. NEGRO, Antonio Luigi; GOMES, Flávio. “Alem das Senzalas e fábricas. Uma história social do trabalho.” http://www.scielo.br/pdf/ts/v18n1/30015.pdf.

13. NÓBREGA Cida e ECHEVERRIA, Regina. Mãe Menininha do Gantois, Uma biografia. Salvador: Corrupio; Rio de Janeiro: Ediouro, 2006.

14. OLIVEIRA, Maria Inês Cortes. Quem eram os "negros da Guiné"? A origem dos africanos na Bahia". Afro-Asia, n. 19/20 (1997), 37-74. "Viver e morrer no meio dos seus: nações e comunidades africanas na Bahia do século XIX". Revista USP, n. $28(1995 / 96)$ p. $174-193$

15. PARES, Nicolau. A Formação do Candomblé - História e Ritual da Nação Jeje na Babia, Campinas, Ed. Unicamp, 2007.

16. PEEL. J. D. Y. Religious Encounter and the Making of the Yoruba. Indiana University Press, 2003

17. REIS, João José. "Domingos Pereira Sodré: um sacerdote africano na Bahia oitocentista." n. 34(2006);

18. Rebelião escrava no Brasil. A bistória do levante dos Malês em 1835. São Paulo, Cia das Letras, 2003, p.308.

19. SAMAIN, Étienne. Quando a fotografia (já) fazia os antropólogos sonharem: $O$ jornal La Lumière (1851-1860) Revista de Antropologia, São Paulo, USP, 2001, v. 44 no 2.

20. SODRÉ, Jaime. Um herói de raça e classe, Salvador, 2001.

21. VERGER, Pierre. Fluxo e refluxo do tráfico de escravos entre o golfo do Benin e a Babia de Todos os Santos dos séculos XVII ao XIX. Salvador, Corrupio, 2002

22. VIANNA, Joaquim Telesphoro Ferreira L. Breves considerações sobre o aleitamento materno. Tese apresentada à Faculdade de Medicina da Bahia. Salvador, Bahia,1855.

23. WETHERELL, James. Brasil, Apontamentos sobre a Babia. Salvador, Edição Banco da Bahia S/A. 